\title{
Taxi Driver - filmatisk portrett av den søvnløse
}

\author{
Martin Scorseses film Taxi Driver fra \\ 1976 er et mesterverk innenfor film- \\ kunsten. Hovedpersonen får ikke \\ sove. Søvnløsheten skyldes både \\ indre og ytre uro. Filmen viser oss \\ nattens brutale New York sett gjen- \\ nom en drosjesjåførs forskrudde sinn.
}

«I can’t sleep nights.» Den 26 år gamle Vietnam-veteranen Travis Bickle, spilt av Robert De Niro (f. 1943), får ikke sove. Og han får ikke noe meningsfullt ut av dagene. Han har prøvd både piller og porno, men det hjelper ikke. Han søker jobb som drosjesjåfør på nattskift.

Åpningsbildene i Taxi Driver, regi Martin Scorsese (f. 1942), er impresjonistisk kunst fra New York «by night». Manhattan er en urban jungel med damp fra underverdenen og neonlys som reflekteres i drosjesjåførens ansikt. Utenfor bilen, sett med hans øyne, er det vold, hor, fyll og forfall. Vi forstår raskt at Travis Bickle er en plaget sjel. Ideen til å bruke søvnløshet som tema skyldes manuskriptforfatter Paul Schraders (f. 1946) egne depressive dager (1). Filmen ble raskt en moderne klassiker, et ikonografisk portrett av nattens New York.

\section{Film noir}

Sjangermessig er dette en videreutvikling av «film noir», svart film, med dunkel lys- setting og dunkle mentale landskaper. Storhetstiden for «film noir» var 1940-årenes Amerika med krimfilmer og thrillere med dystre skjebner, men røttene finnes i tysk ekspresjonistisk film fra 1920-årene. Med den visuelle stilen skulle man forsøke å løfte frem karakterens indre liv og demonstrere den menneskelige psykens kompleksitet (1). Og Travis Bickle er virkelig en noir mann i en noir verden. Han er ensom og ulykkelig - en sann outsider, frakoblet menneskene og språket i en slik grad at han kapsles inn i sine egne forestillinger om hva som foregår utenfor drosjevinduene nattetider. Han ser sin by som en åpen menneskelig kloakk - en paranoid projeksjon av hans eget forstyrrede sinn.

Travis drømmer om regnet som skal skylle vekk skitten. Men regnet kommer ikke. Gradvis blir han mer og mer rasende og bestemmer seg for å ordne opp selv. Han er på jakt etter noen å redde, og finner en utvalgt i den barneprostituerte Iris, spilt av Jodie Foster (f. 1962). Han planlegger så å skyte en senator, men ender opp med å avlive halliken, horekunden og han som leier ut rom til prostitusjonsvirksomheten.

Scorsese forklarer ikke sin karakter psykologisk. Og Travis er kanskje ikke så enkel å forklare. Filmprofessor Robert P. Kolker skriver om Travis at «subjektet uten subjektivitet ikke kan forklares» (1). Men Scorsese viser oss Travis, og en av filmens store kvaliteter er at den stimulerer og frustrerer oss til å ville forstå denne mannen og hans

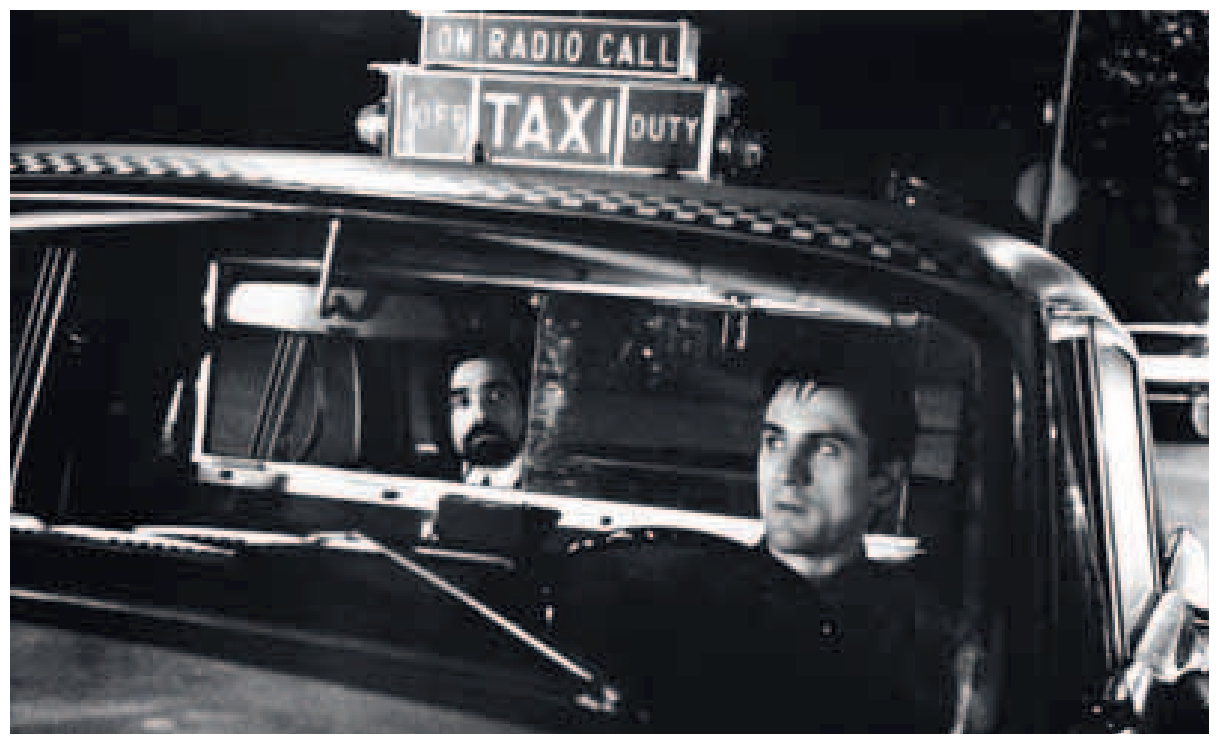

Robert De Niro som Travis Bickle i filmen Taxi Driver (1976). Passasjeren i baksetet er regissør Martin Scorsese. Foto ZUMA Press/SCANPIX

handlinger. Hvor gal er han? Er han en helt? Eller begge deler?

\section{Sosial melankoli}

I sin nye bok fra 2009, Melankoliska rum (2), bidrar den svenske medisinidéhistorikeren Karin Johannisson (f. 1944) til å rehabilitere melankolibegrepet. Hun synliggjør en fenomenologisk rikdom som strekker seg langt utover det atskillig mer reduserende medisinske begrepet «depresjon». Melankoli viser også til trekk ved kulturen, ikke bare ved enkeltpersonen. Og høyst relevant i tilfellet Taxi Driver er ikke uroen bare uttrykt gjennom søvnløsheten, men også gjennom den melankolske figuren anomi. Begrepet «anomi» stammer fra sosiologen Émile Durkheim (1858-1917) og viser til en tilstand av forvirring, utløst av samfunnsmessig mangel på samlende normer. Anomi betegner oppløsning av noe som er fast, tydelig og forutsigbart - slik representerer det et tap. Durkheim knyttet det til moderniteten og markedsøkonomien, til storbyene og til økt selvmordshyppighet (2).

Filmens portrett av den søvnløse kan også ses i en videre kulturell kontekst. Moderniteten er en våkemaskin. Amerikanere sover nå gjennomsnittlig over to timer mindre enn de gjorde for 200 år siden, tenåringene en time mindre enn for 100 år siden (3). New York er et sentrum for kollektiv søvnmangel, omtalt som byen som aldri sover. Den er kjent for å ha sin egen lyd, den hvite støyen, som aldri forstummer - lydene av biler, ambulanser, airconditioning, fra dem som arbeider og fra vinden mellom skyskraperne. I Travis Bickles' tilfelle kommer støyen både utenfra, fra det sosiale, men også innenfra, fra hans eget plagede sinn.

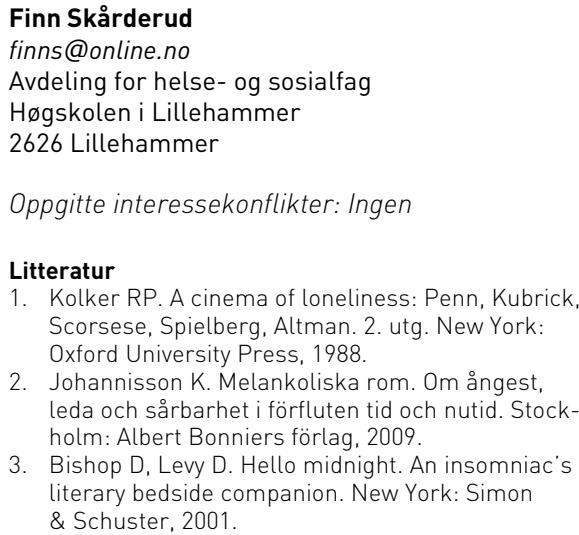

